\title{
The Politicization of the Bureaucracy in Local Government (Case Study in Indonesia)
}

\author{
Sitti Aminah ${ }^{1}$, Tomo HS ${ }^{2}$, Siti Maemunah ${ }^{3}$ \\ Research and Development Agency, Ministry of Home Affairs ${ }^{1,2,3}$ \\ \{sittiaminah.kemendagri@gmail.com ${ }^{1}$ \}
}

\begin{abstract}
A neutral state civil apparatus will guarantee stability in the government. However, the facts show that the local government's bureaucracy gets political intervention in determining positions. The study aims to describe phenomena of intervention politics in the bureaucracy and the factors causing bureaucratic politicization in the local government. Qualitative methods used literature review and regulatory analysis. The study results showed that the intervention politic in the bureaucracy in two problems. First, the high number of violations of civil apparatus neutrality in implementing the local heads election. Second, there is much practice of buying and selling positions in the local government. The intervention politic in the bureaucracy can be analyzed from the local heads' role as a politician and at the same time as a bureaucratic official. As a politician, the local heads often use civil apparatus for their interests during the elections. As a bureaucratic official, the local heads' position is as a Civil Service Officer (Pejabat Pembuat Komitmen), who has the authority to appoint, place, and transfer to civil apparatus dismissal. Local heads have the power to determine the sustainability of civil apparatus careers.
\end{abstract}

Keywords: Politicization of the Bureaucracy; Local Government

\section{Introduction}

The bureaucracy is an implementing institution to achieve government goals. As an implementing institution, the bureaucracy carries out government functions, so that the effectiveness of government is highly dependent on the quality of the bureaucracy. The executor of government functions includes: ensuring security, maintaining order, ensuring justice, carrying out public works, increasing welfare, and preserving natural resources and the environment. Thus, government effectiveness will be realized if supported by a good, innovative, creative, and productive bureaucracy.

So far, the bureaucracy has not achieved the best performance for the progress of the nation. Indications of the bureaucracy's weak performance can be seen from the lower achievement of Indonesia's index of government effectiveness, ease of business, and competitiveness compared to other ASEAN countries; on the other hand, the corruption rate tends to be high as presented in Table 1 . 
Table 1. Competitiveness Index, Easy Doing Bussiness, Corruption Perception Index \& Effectiveness Government Index

\begin{tabular}{lcccccccc}
\hline \multirow{2}{*}{ Negara } & \multicolumn{2}{c}{$\begin{array}{c}\text { Global } \\
\text { Competitiveness } \\
\text { Index (2019) }\end{array}$} & \multicolumn{2}{c}{\begin{tabular}{c}
\multicolumn{2}{c}{ Ease of Doing } \\
Bussiness (2020)
\end{tabular}} & \multicolumn{2}{c}{$\begin{array}{c}\text { Corruption } \\
\text { Perception Index } \\
\text { 2019 (180 negara) }\end{array}$} & $\begin{array}{c}\text { Government } \\
\text { Effectiveness } \\
\text { Index 2017 }\end{array}$ \\
\cline { 2 - 10 } & Rank & Score & Rank & Score & Rank & Score & Rank & Score \\
\hline Singapore & 1 & 84,8 & 2 & 86,2 & 4 & 85 & 1 & 100 \\
Malaysia & 27 & 74,6 & 12 & 81,5 & 51 & 53 & 51 & 76,44 \\
Thailand & 40 & 68,1 & 21 & 80,1 & 101 & 36 & 71 & 66,83 \\
Indonesia & 50 & 64,6 & 73 & 69,6 & 85 & 40 & 98 & 54,81 \\
Brunei & 58 & 62,8 & 66 & 70,1 & 35 & 60 & - & 84,13 \\
Vietnam & 67 & 61,5 & 70 & 69,8 & 96 & 37 & 99 & 52,88 \\
Philipina & 64 & 61,9 & 95 & 62,8 & 113 & 34 & 101 & 51,92 \\
\hline
\end{tabular}

Source: compiled from World Economic Forum, World Bank, Transparency International

The World Bank evaluation for the 1996-2017 period shows that the effectiveness of Indonesian governance is among the lowest in ASEAN, using a scale of 2.5 and -2.5 , the effectiveness of government is measured from five aspects: 1 . the quality of public services; 2 . civil service quality; 3 . degree of independence from political pressure; 4. quality of policy formulation and implementation. 5. The credibility of the government's commitment to implementing the policy. In the last 19 years, the conclusion of measurement that the effectiveness of the Indonesian government is considered flawed, only at -0.32 , lower than the Philippines at -0.03 . While Thailand showed a positive performance, 0.29 , Malaysia reached 1.06. Singapore is the best in ASEAN with a score, 2.27 higher than America, 1.67 (Hulu, 2019).

The data above indicates that there are crucial local government bureaucratic problems that need improvement. One of the critical issues that hinder the Bureaucracy's performance in Indonesia is the politicization of the bureaucracy. The politicization of the bureaucracy means making the bureaucracy work and act by the ruling political interests. The politicization of the bureaucracy is on two sides; it comes from a political party that intervenes in the bureaucracy. The executive itself politicizes the bureaucracy for its interests (power). But both have the same interest, namely perpetuating power (Martini, 2014: 7).

Peters and Pierre (2004) define politicization as "the substitution of political criteria for merit-based criteria in selecting, retaining, promotion, rewards, and disciplining of members of the public service." The consequences of bureaucratic politicization are assumed to be negative. The politicization of administration is seen as less effective than the neutrality of the bureaucracy, which is the basis of the bureaucratic merit system. Thus, the political consequences become negative because the government loses confidence injustice in running government institutions.

Previous research has linked the quality of government bureaucracy to officials' recruitment based on the merit system. For example, the Study of Administration and Northcote-Trevelyan England Report (Northcote \& Trevelyan, 1984) found that hiring officials according to merit would improve the bureaucracy's quality. Evans \& Rauch (1999) found that hiring senior civil servants by merit has been linked to successful socio-economic development. Regarding corruption, a study by Dahlström \& Lapuente (2017) found that implementing a merit system has reduced the level of corruption. 


\section{Methodology}

A qualitative approach was used in this study. Crasswell (2013) mentioned that "qualitative research focuses on the process that is occurring as well as the product or outcome. Researches are particulars interested in understanding how things occur". Data was collected through literature studies to answer the question: what is the empirical condition of the politicization of local government bureaucracy? What are the factors causing the politicization of local government? Processing and analysis used a qualitative descriptive technique, namely: (1) Collecting data, (2) Reducing the data, (3) displays the results of data analysis descriptively, and (4) set up recommendations.

\section{Result and Discussion}

\subsection{Empirical Conditions of Politicalization of Local Government Bureaucracy}

There are three reasons why the bureaucracy must be neutral-first, referring to the German philosopher George Wilhelm Fredrich Hegel, who argued that the bureaucracy has two interests: a mediator connecting the state and civil society. In the community domain, there is a particular interest of various professions and entrepreneurs. In the state domain, it represents the public interest. The bureaucracy in the middle between the government and the intermediary society allows particular interest messages to be channeled into the public interest (Sudrajat, 2015). Second, the bureaucracy is needed as an instrument of public service. The bureaucracy interprets various political decisions into public policies and manages policies effectively, effectively, and efficiently. The bureaucracy must not side with the interests of power politics (Pant \& Gupta, 1990). Third, the bureaucracy is the engine of development. The bureaucracy designs implement and supervise development. In this context, the bureaucracy needs to be free from political interference to function as a public service institution fairly and transparently (Noer, 2014).

However, from the colonial era until the Old Order, the authorities always dominated the bureaucracy. The bureaucracy as a public service was not optimal. On the other hand, the bureaucracy is more politically oriented. The bureaucracy that is very forcefully intervened by politics creates the stigma of bureaucratic politicization (Noer, 2014). In the New Order Era, the bureaucracy was a political instrument used by the ruling class to support Golongan Karya as a government party. Human resources of the apparatus and the provision of funds for Golkar's victory in the general election (Gaffar, 1999: 235).

The same condition also occurs in the reform era; the bureaucracy still shows the patrimonial model's characteristics with the patron-client relationship features, is not accountable, and tends to ignore the merit system. The strength of the power approach and the practice of KKN to achieve strategic positions in Regional Government is evidence of political influence in the government bureaucracy in the regions (Zuhro, 2014).

The politicization of the bureaucracy can be seen clearly during the local head election; the involvement of the bureaucracy (mostly local civil servants) is directly mobilized to support candidate pairs for Regional Head. The main objective is to maintain power in the regional executive branch (Martini, 2013; Rakhmawanto 2017). The politicization of the bureaucracy is getting more vital when the incumbent makes use of the resources of the regional civil apparatus. On the one hand, the regulations require ASN to be neutral, but on the other hand, 
they are forced to ignore neutrality and professionalism to support the incumbent in winning the election.

A motive drove violations of the apparatus's neutrality during the elections for gaining a position in the local government bureaucratic structure (KASN, 2018). Political patronage of regional officials to local heads who are incumbently driven by the local heads can promote, transfer, and demote civil apparatus. On the one hand, a dilemma situation arises; civil apparatus must be neutral and impartial, but at the same time, their careers depend on local heads authorities. Other factors that caused civil apparatus have not been neutral in the elections, including having a family relationship with the candidates; lack of understanding of the rules regarding ASN neutrality; low integrity of civil apparatus, and sanctions for neutrality violations is low.

Although the regulations strictly have forbidden local civil apparatus involved in practical politics such as regional elections, legislative elections, and presidential and vice-presidential elections. Article 2 letter f, Law No. 5 of 2014 states that the implementation of policy and civil apparatus management is "Neutrality." Article No 71 paragraph 1 of Law No.10 of 2016 states that State Officials, Regional Officials, State Civil Service Officials, Members of the National Police, and Village Heads or Lurah are prohibited making decisions and actions that benefit or harm wrong one pair of candidates. But violations of ASN neutrality during the elections have continued to increase significantly from 2015 to 2020, with 1305 cases (Figure 1). These violations revolve around the use of apparatus in the early stages as a "vote gain" and post-election as a regulator of government projects (KASN, 2018).

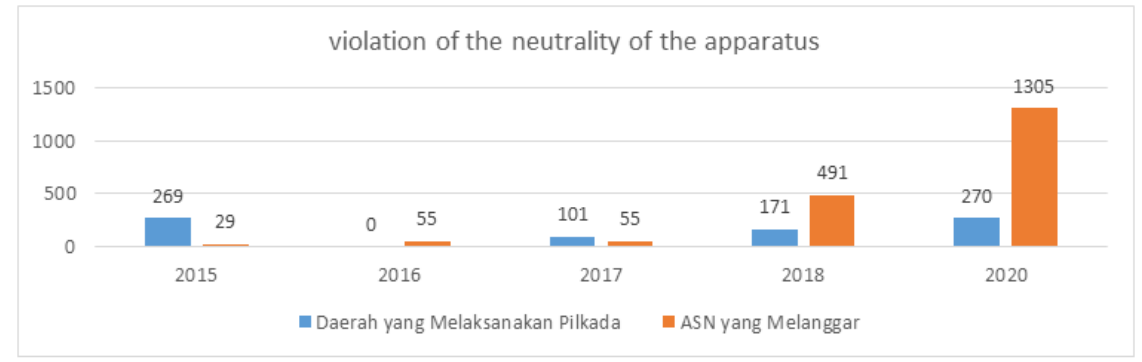

Fig. 1. Violation of the Neutrality of Local Civil Apparatus (Sources: KASN, 2018, 2020)

The politicization of the bureaucracy in the local government can also be seen from political parties' intervention into bureaucratic positions. After the election and regional elections, the winning political parties have lobbed their candidates in strategic positions. The party has candidates who are directed to occupy the positions of regional secretary and head of local work units. The placement of employees in bureaucratic positions has to be based on the merit system, namely capacity, competence, and professionalism. Intervention by political parties into bureaucratic positions is seen as unfair. There are some professional employees but failed to compete with other bureaucrats supported by political parties.

The politicization of the bureaucracy has implications for the massive commercialization of local government positions. From 2015 to 2019, according to the KPK, there were ten areas indicated to have practiced buying and selling positions, namely Aceh, North Sumatra, Bengkulu, Riau, Banten, West Java, Central Java, East Nusa Tenggara, Papua, and West Papua. The research and simulations results by the Muhammadiyah Youth Anti-Corruption Madrasah Center Association (MAK) found that around 90 percent of 21,000 local office heads in 34 provinces and 514 districts/cities are trafficked. It is also argued, based on samples taken in 10 regions, the highest price for a position is IDR 400 million, and the lowest price is 
IDR 100 million (Katharina, 2018). The simulation conducted by KASN found that potential state losses in the sale and purchase of positions reached IDR 102 trillion, assuming a calculation presented in Table 2 .

Table 2. Potential State Losses in Position Sale and Purchase Transactions

\begin{tabular}{|c|c|c|c|c|c|}
\hline No & Positions & Number & $\begin{array}{l}\text { Percent of Sale } \\
\text { Government } \\
\text { Position } \\
\end{array}$ & $\begin{array}{c}\text { Bribe Rates } \\
\text { (Million) }\end{array}$ & $\begin{array}{c}\text { Total Bribe } \\
\text { (Million) }\end{array}$ \\
\hline 1. & $\begin{array}{l}\text { The High Leadership Position } \\
\text { (Utama/Madya) } \\
\text { Ministry/Institution/Province }\end{array}$ & 1.841 & $10 \%$ & 500 & 92.050 \\
\hline 2 & $\begin{array}{l}\text { The High Leadership Position } \\
\text { (Pratama) K Ministry/Institution/ } \\
\text { Province/ District/City }\end{array}$ & 28.744 & $70 \%$ & 250 & 5.320 .200 \\
\hline 3. & Administrators and Supervisors & 412.696 & $70 \%$ & 150 & 43.333 .800 \\
\hline
\end{tabular}

The implementation of open selection for high leadership positions (open bidding) based on the mandate of Law No. 6 of 2014 concerning the state civil apparatus has not been carried out by the regional government. Out of 600 government agencies (34 ministries; 39 nonministerial government agencies; 78 non-structural agencies; 34 provincial governments; and 508 district/city governments), 57 percent have not selected positions, and only 43 have implemented open selection for high leadership positions.

Political intervention to the bureaucracy has caused civil apparatus got dissatisfaction. Because career development for civil apparatus is no longer measured by competence and work performance, but political considerations more color it, civil apparatus has become fragmented based on support groups. Furthermore, the politicization of the bureaucracy results in a corrupt and inefficient bureaucracy (Antlov, 1994). Significantly with Antov's statement, the data shows that the elections' implementation has increased the number of corruption in local government over time 2004-2020, as presented in Table 3.

Table 3. Governor/Regent/Mayor/Deputy and Echelon I, II and III Officials facing Corruption Crime 2004-2020

\begin{tabular}{cccccccccccccccccccc}
\hline No & Jabatal & 2004 & 2005 & 2006 & 2007 & 2008 & 2009 & 2010 & 2011 & 2012 & 2013 & 2014 & 2015 & 2016 & 2017 & 2018 & 2019 & 2020 & Jumlah \\
\hline 1 & Governor & 1 & 0 & 2 & 1 & 1 & 2 & 1 & 0 & 0 & 2 & 3 & 3 & 1 & 1 & 2 & 1 & 0 & 21 \\
2 & Regent Nayor Vice & 0 & 0 & 3 & 6 & 6 & 5 & 4 & 3 & 3 & 3 & 12 & 4 & 9 & 13 & 30 & 8 & 4 & 122 \\
3 & Echelon III dan III & 2 & 9 & 15 & 10 & 22 & 14 & 12 & 15 & 8 & 7 & 2 & 7 & 10 & 43 & 24 & 26 & 7 & 230 \\
& Nuruber & 3 & 9 & 20 & 17 & 29 & 21 & 17 & 18 & 11 & 12 & 17 & 14 & 20 & 57 & 56 & 35 & 11 & 373 \\
\hline
\end{tabular}

Sources: https://www.kpk.go.id/id/

The State Civil Apparatus Committee (KASN) has an essential role in evaluating and supervising civil servants' neutrality. Article 33 of the ASN Law regulates the authority of KASN is to manage the stage of the process of placement positions, including the formation of agency selection committees, an announcement of vacancies, implementation of selection, proposing names of candidates, stipulating and inaugurating high-ranking officials; supervise and evaluate the application of the principles, fundamental values.

Supervision is also carried out on the code of ethics and behavior of the civil apparatus. However, in its implementation, the performance of KASN is seen as weak. Article 32 (3) of the ASN Law stipulates that the Civil Service Officer (PPK) and Authorized Officials are required to follow up on the results of KASN supervision of filling High Leadership Positions (JPT) and evaluate the application of the principles, basic values, and code of ethics and code of conduct for ASN Employees. The level of compliance of Civil Service Officers (PPK) to 
follow up on KASN recommendations for violations of basic values, code of ethics, code of conduct (NDKEKP), and civil apparatus neutrality have only reached 73.3 percent. Five hundred seven recommendation letters by KASN in periods January - December 2019, only 224 (44 percent) of the recommendations were followed up by the Civil Service Officer (PPK).

\subsection{Factors Causing Politicization of Local Government Bureaucracy}

Conceptually, the bureaucracy's politicization has occurred because of the local government's political and administrative dichotomy practice. Overlap of roles is on the one hand as a public servant and on the other as a political actor. This situation has triggered a conflict of interest in the local government bureaucracy and has damaged the Bureaucracy's performance (Thoha, 2007). Unclear authority limitation between the political domain, which is the duty of political officials, and the administrative domain, which is the duty of career officials. This political and administrative dichotomy has led to the dual loyalty of bureaucratic career officials. They must be loyal to the government as public servants, but at the same time, they must dedicate themselves to their leaders who affiliated political parties (Rakhmawanto, 2017). Political positions are positions obtained through political mechanisms. Political officials have a constitutional mandate to hold political office through general elections. Political tenure is obtained based on the constitutional mandate.

The unbalanced relationship between bureaucracy and politics in the local government has caused the bureaucracy dominated by political interests rather than the civil apparatus's performance and competence. The concentration of officials is not to work but to build dynamic relationships with politicians to secure their positions (Prasodjo and Rudita, 2014). The politicization of the bureaucracy has caused the performance of public services to below. Still, it has created bureaucratic conflicts and disharmony of relations between civil servants because each competes for bureaucratic positions. There is no guarantee, work performance and competence become the basis for career development to a higher level. This condition has created irony in local governments.

The main factor causing the politicization of the bureaucracy, namely the regional head position as a political office but having the authority as an official of personnel guidance, needs to be criticized because it opens opportunities for political intervention. The mandate of Article 53 of Law No. 5/2014 on ASN is as follows: "The President as the highest authority in the development of ASN can delegate the authority to determine the appointment, transfer, and dismissal of officials other than the main and middle high-ranking officials, and functional officials with main expertise: a. Minister in the ministry; b. Heads of institutions in nonministerial government agencies; c. Secretary-general at the secretariat of state institutions and non-structural institutions; d. Governor in the province; and e. Regents /mayors in regencies /cities". The heads of agencies and local heads (governors, regents, and mayors) are positioned as Civil Service Officers (PPK) who can appoint, transfer, and dismiss ASN employees in the regions.

The implementation of Article 53 of the ASN Law has become the main reason for the outrageous acts of local heads. The authority as PPK is very vulnerable to being abused by the local heads; for example, the euphoria of political officials' political powers is shown by massively eliminating bureaucratic positions. A study conducted by Stein found that the role of local heads as PPK has resulted in buying and selling Civil Servant Candidates' recruitment (CPNS). The recruitment of CPNS is used as a commodity to get money for the CPNS who are selected in this way; it is proof that they do not have work competencies that are by work 
needs. There is an accumulation of employees in one place due to employee placement without performing performance analysis.

Besides the regulatory factors described above, the driving factors caused bureaucrats are co-opted by politics, including 1 . The attitude of politicians or local heads does not show an example as a statesman. Based on the cases mentioned above, the cause of bureaucratic involvement in politics is precisely the leaders' pressure. Local heads, which are generally politicians or party cadres, often do not act professionally. They have used the bureaucracy for the benefit of their political parties. 2. The patron-client political culture in the bureaucracy has caused bureaucrats to serve and provide political support to leaders. I hope that if their leader is re-elected or the political party wins, they will get a promotion. 3. Excessive personal fanaticism to express his political choices. 4. Leaders in the regions who are not firm in upholding civil servants' neutrality rules are involved in practical politics. 5. Weak law enforcement and sanctions do not create a deterrent effect (Firnas and Maesarini. 2011).

\section{Conclusions}

The empirical condition of the politicization of the bureaucracy in the local government bureaucracy has weakened the bureaucracy, especially hurting violations of the civil apparatus's neutrality, commercialization of positions, and intervention of political parties in local government bureaucratic positions. Following the ASN Law, the local head's authority as a Civil Service Officer (PPK) has opened up more significant opportunities for politicizing the bureaucracy in the regional government.

To limit political intervention to the bureaucracy necessary to revise Article 53 of the ASN Law, which regulates local heads' authority (Governors, Regents, Mayors) as Civil Service Officers. The government must remove this article to separate political positions: the domain of political parties and career positions, which are the state apparatus's civil domain as policy implementers. Then PPK authority is given to the regional secretary as a senior bureaucrat in the region.

The next option is the application of a merit system in the management of civil apparitions. Promotion based on the following aspects: comparison between competencies, qualifications, and requirements required by the position, assessment of work performance, leadership, cooperation, creativity, and consideration of the civil servant performance appraisal team at Government Agencies, regardless of gender, ethnicity, religion, race, and class. Promotion with a robust approach is carried out humanely by accommodating a merit system and carried out by neutral officials.

\section{References}

[1] Corruption Eradication Commission: Politicization of the Bureaucracy in Indonesia, https://www.antaranews.com/berita/1877152/kpk-pengusaha-dominasi-calon-kepaladaerah-pilkada-2020 (4 December 2020)

[2] Dahlström, C., \& Lapuente, V. (2017). Organizing Leviathan: Politicians, Bureaucrats, And The Making Of Good Government. Cambridge University Press.

[3] Evans, P., \& Rauch, J. E. (1999). Bureaucracy and growth: A cross-national analysis of the effects of "Weberian" state structures on economic growth. American Sociological Review, 64(5), 748-765. https://doi.org/10.2307/2657374 
[4] Firnas, A.M and Maesarini, I.W. 2011. The Problem of Politicalization of the Bureaucracy in Indonesian Politics. Journal of Policy and Management. Vol 5 (2). P. 20-35

[5] Gaffar, Affan. 2006. Indonesian Politics. Yogyakarta: Pustaka Pelajar.

[6] Gaffar, Affan. 1999. Indonesian Politics Transition Towards Democracy. Yogyakarta: Pustaka Pelajar

[7] Hulu, Edison. 2019. The Effectiveness of the Government of Indonesia is Worst in ASEAN in the Last 19 Years! https:/www.kompasiana.com/yahowu/5c6b686aab12ae2a7576a60b/efektivitaspemerintah-indonesia-terburuk-di-asean-dalam-19-tahun-terakhir.

[8] Martini, R. 2013. The politicization of the Bureaucracy in Indonesia. Journal of Political Science. Vol. 1 (1). P. 118-133.

[9] Noer Hendra Hamka. 2014. The Neutrality of the Indonesian Bureaucracy. Study of the New Order Period to the Reform Order. PT Elex Media Komputindo: Jakarta

[10] Pant, A.D, \& Gupta, S.K. 1990. Bureaucracy, development, and change: contemporary perspective. New Delhi: Segment Book Distributor.

[11] Prasojo, E. \& La Ode Rudita. 2014. State Civil Apparatus Law: Changing the DNA of the Bureaucracy. Journal of Governmental Science. 45 Edition. P. 13-33.

[12] Prasodjo, E. 2012. Acceleration of Bureaucratic Reform as the Key to the Success of National Development. Negarawan- State Secretariat Journal Republic of Indonesia. No 24.

[13] Pudjo Rahayu Rizan, Politicization of the Bureaucracy in the elections https://www.antaranews.com/berita/1258020/politisasi-birokrasi-dalam-pilkada, $\quad 21$ January 2020.

[14] Peters, B.G \& Pierre, J. 2004. Politicization in comparative perspective: The quest for control (pp. 41-54). Routledge.

[15] Rakhmawanto, A. 2017. The Perspective of Politicalization of the Bureaucracy and the Role of Civil Service Officers in the Government Bureaucracy. Journal of Administration and Public Policy, Vol 3 (1). P. 19-32

[16] Rakhmawanto, A. 2018. The dichotomy of the merit system and the politicization of the bureaucracy in the appointment of ASN positions. Policy Brief, No 019, 2018. Civil Apparatus, Center for Human Research and Research: Jakarta

[17] Sudrajat, T \& Karsona A.M. 2015. Questioning the Meaning of the Neutrality of Civil Servants in Law No. 5/2014 on State Civil Servants. https://doi.org/10.14710/politika.1.1.2010.118-133

[18] Stein Kristiansen. 2009. Recovering the Costs of Power: Corruption in Local Political and Civil Service Positions in Indonesia, sebuah makalah, presented on CSIS Meeting 2009, no published.

[19] State Civil Apparatus Commission.2018. Supervision of the Neutrality of the State Civil Apparatus. Jakarta: State Civil Apparatus Commission

[20] Tatang Sudrajat, 2015. The Neutrality of Civil Servants and the Future of Democracy in the Pilkada 2015 Simultaneously. Journal of Administrative Sciences, Vol 12 (3), P. 358.

[21] Thoha, Miftah. 2007. Bureaucracy \& Politics in Indonesia. Jakarta: Rajawali Pers.

[22] Zuhro, S.2014. Bureaucracy, Democracy and Politics in Indonesia. Journal of Governmental Science. 45 Edition. P. 86-105 